\title{
The impact of hazards on the urban tissue - 3-D representation and digital databases
}

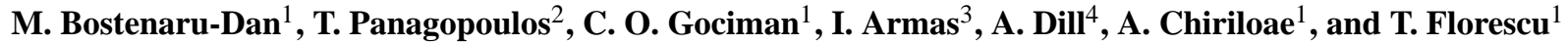 \\ 1 "Ion Mincu" University of Architecture and Urbanism, Bucharest and Sibiu, Romania \\ ${ }^{2}$ University of Algarve, Faro, Portugal \\ ${ }^{3}$ University of Bucharest, Bucharest, Romania \\ ${ }^{4}$ Karlsruhe Institute of Technology, Karlsruhe, Germany
}

Correspondence to: M. Bostenaru-Dan (maria.bostenaru@iaim.ro)

Received: 15 February 2013 - Revised: 19 May 2013 - Accepted: 28 May 2013 - Published: 28 June 2013

\begin{abstract}
The focus of this ongoing research is the 3-D modelling of changes in the urban tissue by catastrophic events. For this purpose protected areas in the centre of Bucharest were considered. The principle idea was to establish a reasonable amount of 3-D city models in GIS and CAD and examine how they can be useful in and used for sustainable development decisions, in the case of protection against hazards.
\end{abstract}

\section{Introduction}

Up to the moment of this research and to the knowledge of the authors, there is not yet a 3-D city model of the city of Bucharest. Despite existing requests, Google has not made available oblique photos from multiple angles which would enable one to build such a model through crowd sourcing. In this respect Bucharest lags behind other capitals, or even initiatives for cities affected by hazard events such as l'Aquila (Italy). However, enthusiasts have modelled single buildings, which are available on Google Earth; although, the models are not accurate in all cases: as for Balta Alba, one of the mentioned 1970s wards, blocks of 4 storey flats are represented as 10 storey flats.

For 3-D modelling we have chosen two areas of the city. The models are comprised of two areas of the city that were affected differently by the systematisation intervention in the communist period: the historical centre, which remained nearly unaltered, and the civic centre area, where blocks of flats were built in front of the remains of the former tissue after demolitions were finished for the Unirii boulevard. The
3-D model displays the relationship between buildings of different heights. Before 1930 the highest buildings were the public buildings, mainly of French architectural influence; the rest of the tissue was formed by single family one or two storey houses. It was followed by the first boulevard with high rise buildings (19th century boulevards had at most midrise). In the case of the N-S Magheru Bălcescu boulevard, the urban intervention placed a front of high rise buildings in front of low rise single houses with garden.

A 3-D city model based on an existing GIS model was elaborated. In this case the 3-D modelling helped, apart from understanding the morphology, to assess the vulnerability through classification. The historic centre presents a different tissue that is most visible in the 3-D model. This model was created using GIS programming and thus the items can be connected to values, i.e. semantically enriched. In this case, the buildings were not single isolated houses with gardens, but fronts of Western European tradition, which housed merchants coming from the German town of Lipsca (Leipzig). The French influenced public buildings follow the model of houses with gardens, which is also the case for the People's House/Parliament Palace. Finally, some of the buildings in the modelled area served as example for the architecture of the civic centre. The area modelled in Fig. 1 using CAD software is the southern continuation of the historic centre. The interaction of different heights visible in the 3-D model displays different layers of the evolution of the city: the tower marking the end of the historic $\mathrm{N}-\mathrm{S}$ axis of the city west of the historic centre, the church translated and hidden behind blocks of flats, the dominant size of the French-type public buildings, and the compact front of buildings with no 

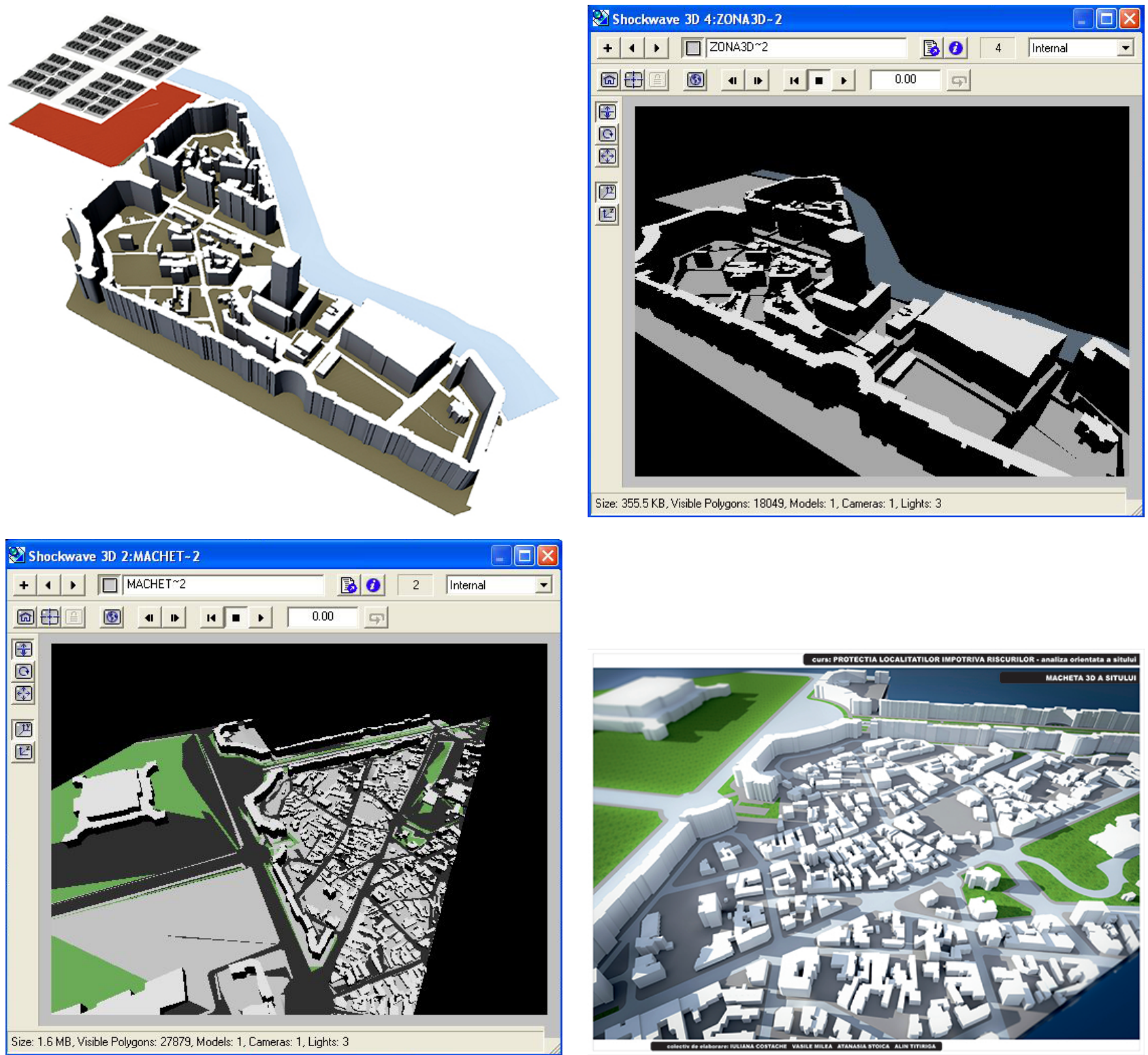

Fig. 1. CAD model of areas exposed to multi-hazard, destructured by former interventions in the communist time, a protected zone in Bucharest and their import in real time 3-D applications. The 3-D model helps to identify the free spaces in relationship with emergency housing. Above: Alexandra Chirloae, below: Iuliana Costache, Vasile Milea, Atanasia Stoica, Alin Titiriga.

differentiated architecture behind which there are remnants of the former urban tissue. Three-dimensionally modelling may help the city development strategy with such things as localisation of emergency housing in the adjacent park. The CAD model saved as .obj file may be used in software to create a web 3-D application. This enabled us to create a dialogue of the model, which can be walked through in real time (OO programming) and the Google image of the area, in order to compare proposed changes given by the urban strategy. A prototype on how to compare such changes was shown in Bostenaru Dan (2012a). The aim of the 3-D models was to build a basis for decision support in earthquake mitigation.

\section{Methodology}

The focus of this ongoing research, supported by both national funded projects in Romania and international cooperation networks, was the digital modelling of changes in the urban tissue by catastrophic events. For this purpose, protected areas in the centre of Bucharest were considered. The purpose itself was to establish to what extent 3-D city models are useful, usable and used for sustainable development decisions, which is in this case the protection against hazards. 
Research steps entailed

1. Defining urban planning layers, historic view: theoretical framework.

a. Historic development in Bucharest (misuse, vulnerability, emergency planning and impact of the 1977 earthquake).

b. Defining immersion in space and time:

i. representing memory (classification of literature related to the memory of disasters);

ii. the role of games vis-a-vis the role of literature.

2. Investigation of the role of memory in representation of ruins in reconstruction after the earthquake.

3. Formulation of definitions for semantic enrichment:

a. Comparison of the models to other 3-D historic models.

b. Sketching future works (building a digital database).

The underlying research project for which digital representation was intended is on European buildings which were subjected to earthquakes with reinforced concrete structures from the first half of the 20th century. Rarely has the structural system of buildings been documented in architectural history, and even more rarely have buildings been listed as monuments because of it. The gap will be filled by a database of such buildings, using photographic material already gathered. Further, a taxonomy and ontology for retrofit elements for these buildings is proposed. From the survey, over structural intervention to economic computations, the same retrofitted and retrofitting elements are defined.

Structural simulation results will be tested on applicability for economic impact analysis through (1) The Monte-Carlo simulation for extension, (2) comparison with real projects, and (3) comparison with experimental results from European laboratories databases. A decision support system, employing the newest developments from game theory for economics and drama theory for conflict solving and ontology approach, will be developed.

\section{Results}

In this paper we present the results of the analysis using a 3 step process to model three-dimensionally the areas that are part of the research.

The GIS database for Bucharest was used for the historic centre and for the protected zone "Modernist boulevard" (Fig. 2), which was the most affected by the 1977 earthquake. For the vulnerable zone affected by the Ceausescu period demolitions, the CAD model was used.
In step 1 elements of the current situation were listed.

- User types: disaster management decision maker, disaster management researcher, city managers.

- Target groups: the emergency inspectorate Bucharest, units of public administration (municipality and sectorial administration).

- User needs: identify vulnerable buildings and prioritise them for intervention, identify strategic zones for intervention in an emergency situation (ex. location of emergency housing).

- Tasks to be performed: GIS query and 3-D visualisation, navigation.

- Identification of 0-D, 1-D, 2-D, 3-D data used: GIS shape map of the historical centre of Bucharest, extruded to 3-D (2.5D).

- Specific process: extrusion.

- Complementary data (non 3-D): tables with data on the buildings (age, height, construction material, listed as monument or not, number of inhabitants, etc.).

Then also the potential improvement of the model was listed:

- 3-D data needed (enrichment - new objects): detailing of the extruded objects, ex. With roof shapes, texturing of the objects to see possible relationships between openings (a factor in structural identification and vulnerability assessment); or

- information which has to be added to 3-D objects (enrichment - new attributes ...): recognition of the structural system through a matrix of characteristics from which the building material of the structure can be recognised.

Borzi et al. (2008) simplified analysis of vulnerability of populations of buildings requires either this information to be contained in the table or different LOD (interior), as we have suggested for the SketchUp models in Google Earth, which, however, has no database analysis possibilities. Therefore, the exchange formats are important, in this case the connection of CAD and GIS data. This analysis can be the basis for economic efficiency computations used in decision making.

In step 2 the impact of new equipment (devices) on result of step 1 was assessed: for acquiring the new data mentioned at step 1 the digitalisation of building surveys is needed, either through scanning of the paper survey and converting it into CAD or through direct digital scanning (ex. laser, or laser point measurement of the spans). 


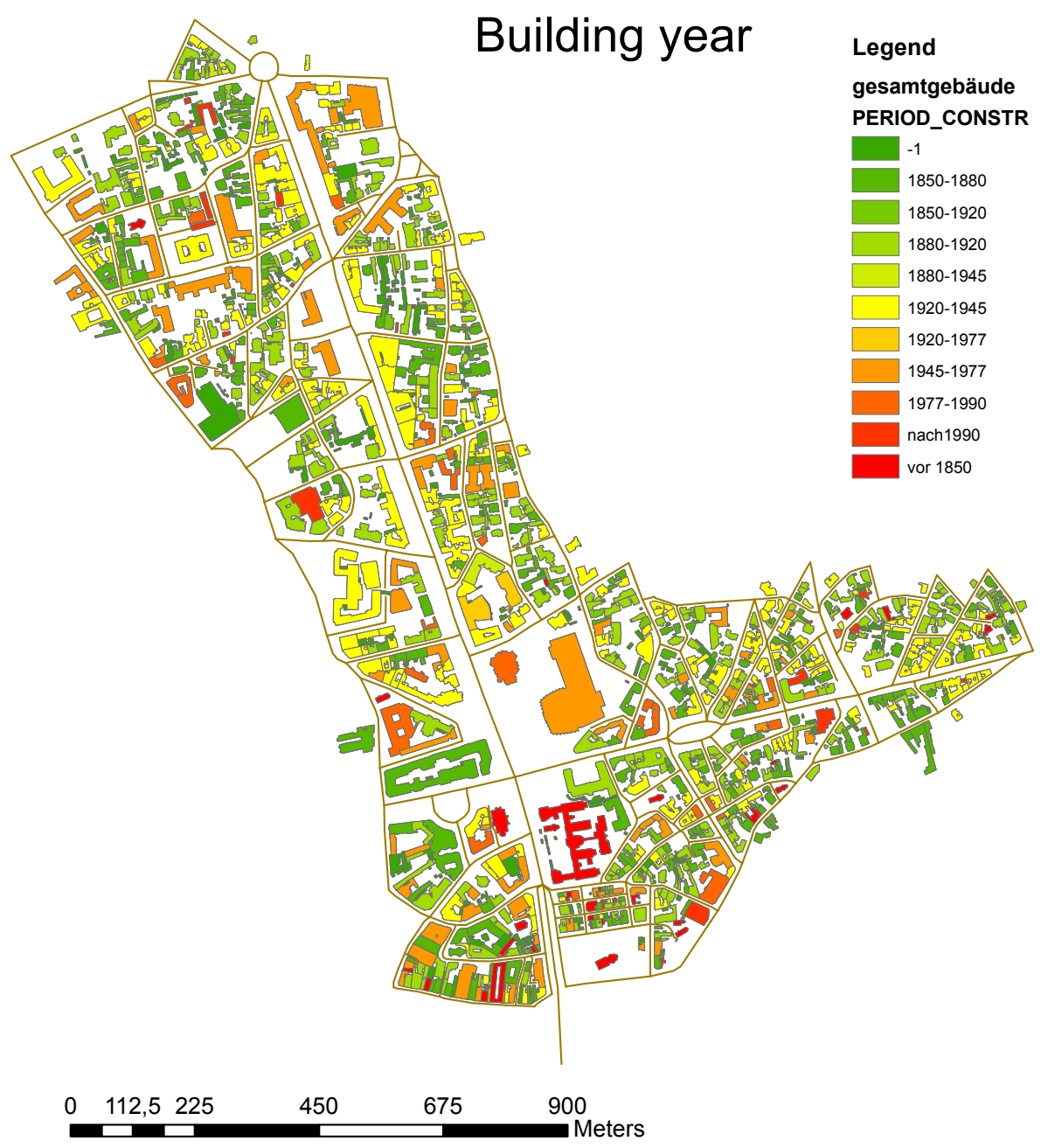

Fig. 2. GIS map of the areal investigated in SFB461, displaying the age of the buildings along the N-S Modernist boulevard.

In step 3 the focus was on the creation of information:

- Identification of 3-D information created (through the processes) visualisation of the volumetric relationships in the studied area, with possibilities the identification of the vulnerability enhancement of the vicinity of different buildings and of identification of potential security nodes (concept by Gociman, 2006), for location of emergency services.

\section{Discussion}

There are no 3-D city models of Bucharest; such models, as noticed in the COST action TU0801 "Semantic enrichment of 3-D models for sustainable urban development", are sparse in Eastern Europe. Even Google Earth does not offer oblique imagery and only a few buildings are modelled based on the enthusiasm of individuals. Within the project HERA "Multihazard and vulnerability in the seismic context of the city of Bucharest", the 2-D GIS data used for analysis have been extruded to $3-\mathrm{D}$. This extrusion is only a small part of the project, the aim of which is to identify procedures to correlate the data needed by different actors in vulnerability assessment. The socio-economic vulnerability component is also considered. The GIS component permitted a number of statistical operations and analyses as compared to traditional urban plans.

The narrow study area is the historic centre of Bucharest, which has not been affected in the earthquake impact and post-earthquake reconstruction, featuring mainly low-rise masonry buildings. The really vulnerable and affected part is situated north of the historic centre, in the interwar development, and that is where the extension of the methodology is aimed to be focused next. The 3-D extrusion permits a better visualisation in the vulnerability analysis with effects in elaborating the intervention strategy by decision makers and local authorities, based on the relationship between built volumes among themselves and with free spaces. Such elements of 
Table 1. Check list to establish the structure of the buildings in the surveyed area.

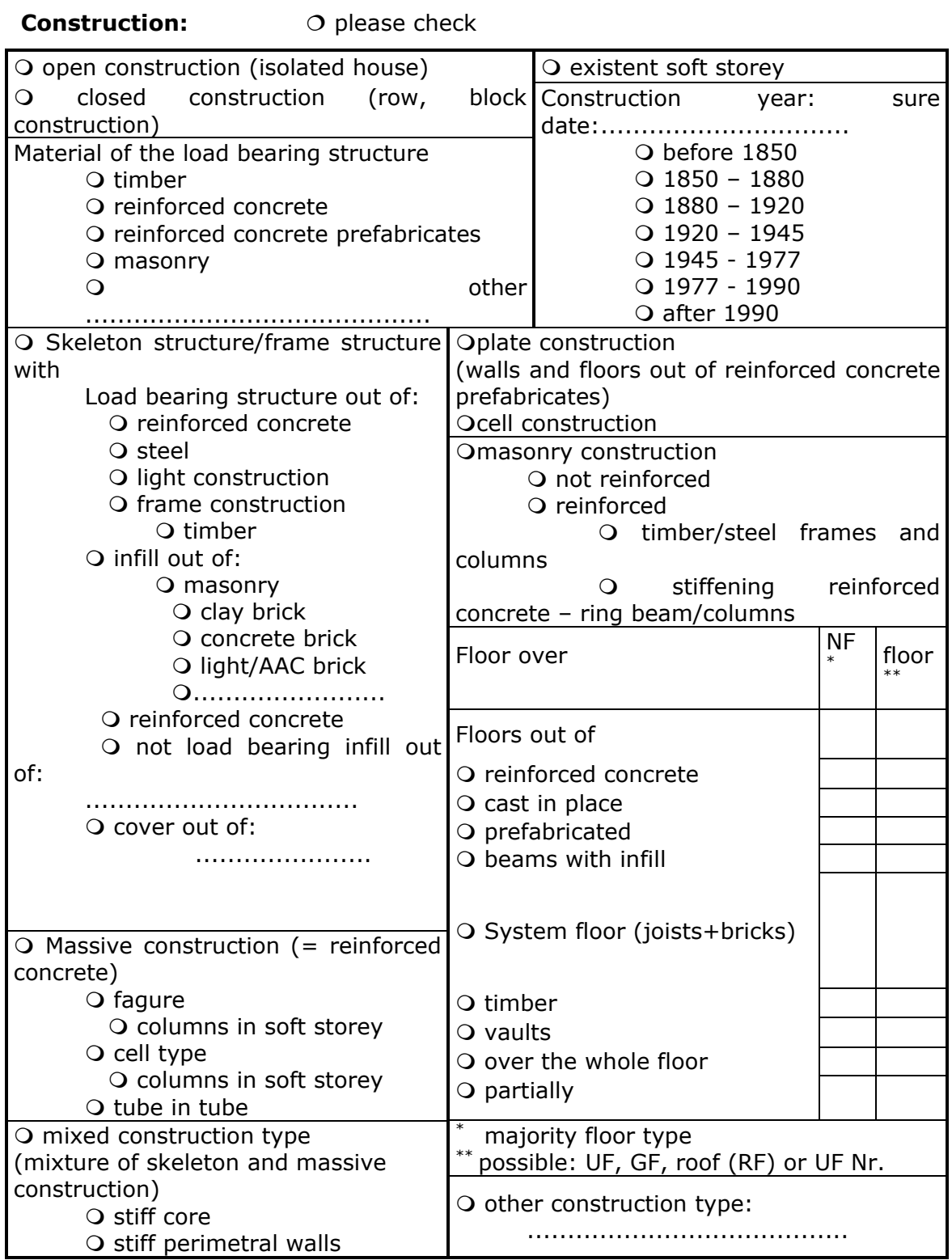

disasters management shall be contained in the master plans. For further multi-criteria analysis different levels of detail of the 3-D models would be required.

The extrusion algorithms have been developed by the ASE partner and are applicable for any GIS depiction of an urban area. However, there is no web interface for making it publicly available. Similar conversions from 2-D to 3-D GIS can be done with CityEngine (an ESRI product).

The GIS 3-D modelling was also put in the context of the other analysed methods, and a new concept was developed (Bostenaru Dan and Panagopoulos, 2012). This concept has now to be applied for Bucharest. Aim of the short project at the Karlsruhe Institute of Technology was to intro- duce the Romanian Modernist heritage by means of digital methods (see report in Bostenaru Dan, 2011 and Bostenaru Dan, 2013b). In 2000 when the applicant was working at the host institution for this Short Visit Grant, a survey of an area comprising 1500 buildings in the centre of Bucharest was performed and the data introduced in a GIS system (Fig. 2).

A questionnaire (Table 1), was developed to collect data on buildings vulnerable to earthquakes, information included currently in the GIS database. For the view on the economic efficiency envisaged for example in our methodology, other data are needed, as detailed for emblematic buildings in Table 2 . The area surveyed includes the main $\mathrm{N}-\mathrm{S}$ boulevard of Bucharest, an unique section in Europe being built in the 
Table 2. List of vulnerable architecturally significant buildings in Bucharest (risk category I).

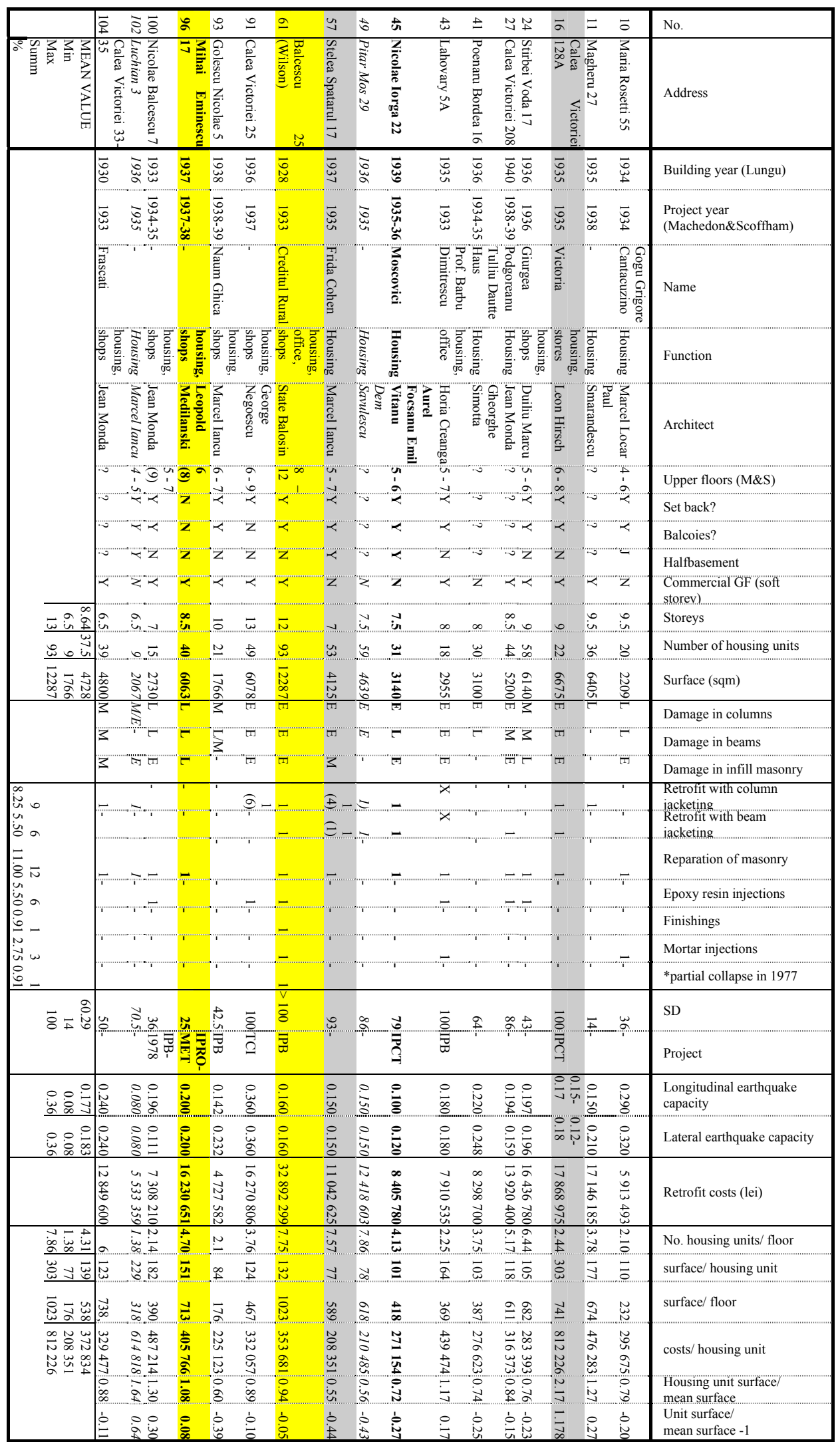


Table 3. List of monuments in the area comprised by the survey for the GIS database.

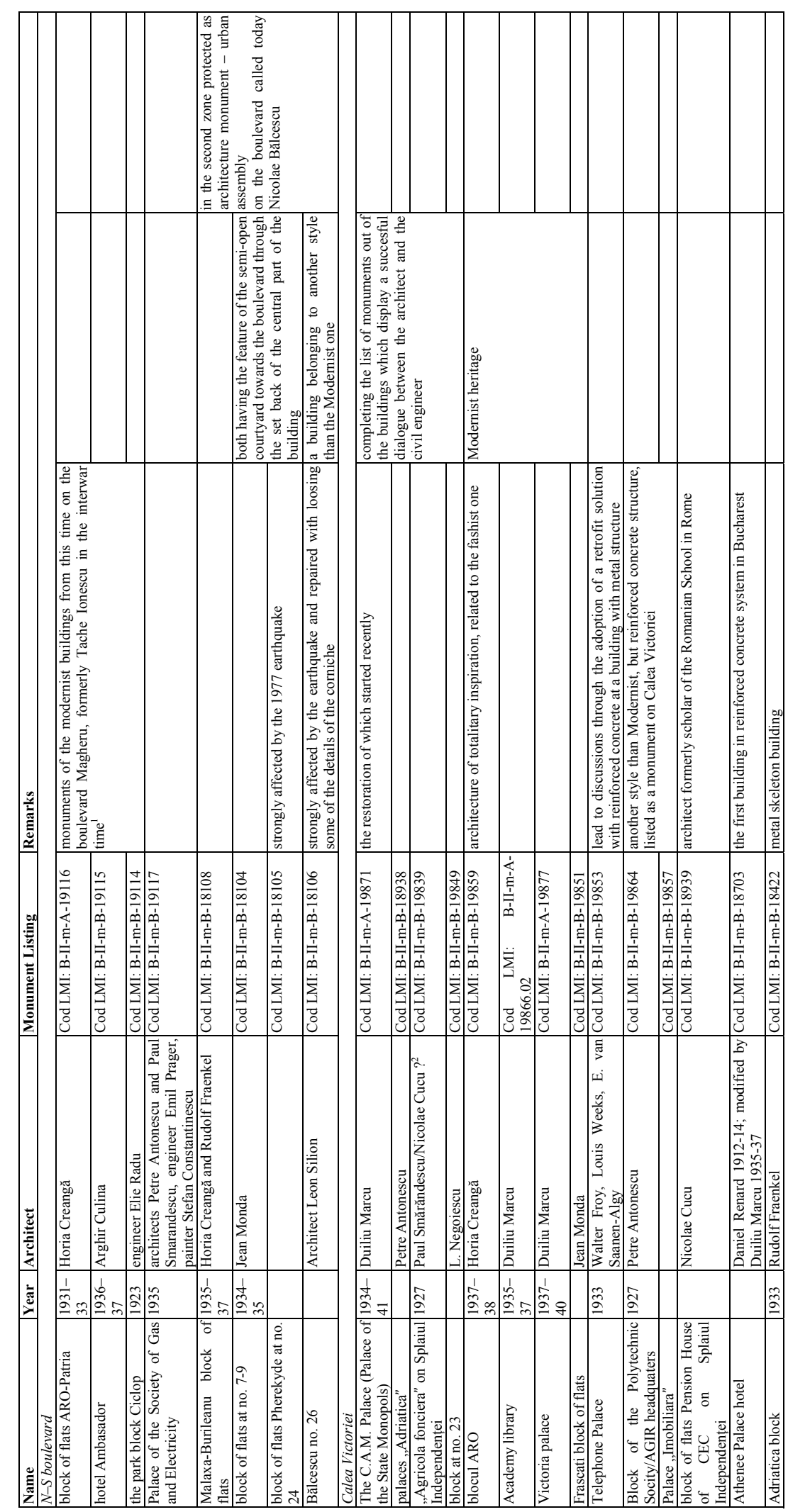

\footnotetext{
${ }^{1} \mathrm{http}: / /$ www.apmnir.ro/map.php
}

${ }^{2}$ Contradictory attributions in various sources: Mariana Celac et al. (2005); Smărăndescu (1942); and Prager (1979) 
interwar period. Today the boulevard is facing conservation problems, in the context of thermal isolation and seismic retrofit. A recent example to be analysed and altered is a multistory building by German architect Rudolf Fränkel, who immigrated to Romania during this time.

Data on architect, monument value, and urban planning protected zone value have to be introduced; the inclusion of such elements in the architecture curricula is the focus of architecture training in Karlsruhe with regard to the geo-innovation planning network (http://www.stqp. uni-karlsruhe.de/index.php?option=com_content $\&$ view $=$ section\&layout=blog\&id=25\&Itemid=83), where it is planned to later present the results. We also include the typology into the digital taxonomy overview of the Global Earthquake Model, with corresponding glossary entries (public testing of GEM taxonomy at http://www.world-housing. net/related-projects/share-your-knowledge-of-buildings/ building-taxonomy-summary-reports). Alternative database applications for the photographic and textual data on these buildings for the web (ex. for the DOCOMOMO registries http://www.archi.fr/UIA/) will be considered. Selected architect's biographies are to be included in the Routledge Encyclopedia of Modernism (http://remodernism.wikispaces.com/ an encyclopedia being understood as another form of thesaurus and ontology).

We detail here some results concerning the monument status of emblematic buildings in the surveyed area. The list of monuments of the typology with early reinforced concrete skeletons is too long to be completely included here, and reference was made to those dealt with in Bostenaru Dan $(2013 a, b)$. Table 3 shows a selection of those identified. Buildings affected by the 1977 earthquake, such as the blocks "Turist", "Podgoria", "Wilson", are not protected individually, but as part of the protected zone and the architecture monument assembly. Moreover, the remarkable block of flats Elena Ottulescu by Horia Creangă, through its Raumplan in multi-storey building is not listed as a monument (http://www.monumenteromania.ro/). With regard to urban planning, the same zone of the "Modernist" boulevard Magheru is a protected zone: the protected zone no. 4, with interwar buildings having the maximal degree of protection (see a map of the protected zone at http://www.pmb.ro/ servicii/urbanism/zone_protejate/docs/magheru.pdf), mainly for the urban planning assembly (street pattern, continuous fronts, height range).

Protected zones were defined in 1999 as an urban planning instrument. Depending on the importance for the city, for the urban tissue and the value of the built substance, 12 out of the 94 protected zones have been detailed (2005-2007). These are zones in which the urban image determined by the natural frame, the historical zones, the typology of the built substance and the function have to be conserved. Development is not excluded, rather it is permitted and encouraged in some conditions and determined by the specifics/identity of the zone that emphasises its character; therefore keeping the urban quality. The document defines the protection relationship: keeping, modifying, demolishing, depending on the value attributed to the buildings. Retrofit interventions are allowed. The parcels have to be kept unchanged. The zone is larger than the one studied and spans to the Unirii Place. The architecture assembly "Bd. General Gheorghe Magheru" Bd. Magheru Gheorghe g-ral, between str. Pictor Verona and str. C. A. Rosetti, is a historic monument as well (Cod LMI: B-II-a-A-19113); furthermore, this the "Architecture assembly 'Bd. Nicolae Bălcescu'" between str. C. A. Rosetti and str. Batiştei is also a historical monument (Cod LMI: B-II-aB-18103). The protected constructed zone overlaps with the one studied by SFB461 (Fig. 2).

\section{Conclusions}

The functional evolution of the city can be displayed for the city as a whole at the level of 2-D plans, and for selected areas which are considered representative through 3-D models. The 3-D model displayed the reflection of the function in the urban morphology, since the function was based on the urban activities which describe the urban life, while the spaces and the buildings defining it served the urban frame. Each stage in the existence of the city is a singular urban-existence, as represented by the city plans. But the urban form and transformation are also defining risk and vulnerability and of the urban tissue (Florescu, 2006), which is why 3-D was employed as an instrument to study the morphology with the aim of vulnerability and risk management studies. 3-D was useful in this case, and used in research projects from the field.

Acknowledgements. Research presented in this paper is based on work in the Romanian funded national projects, "Urban blocks in central protected area in multiple hazard approach assessment,mapping and strategies for risk mitigation.case study: bucharest-destructured zone by razing occurring in communist period" principal investigator C. Gociman (which funded the presentation at the conference), HERA, principal investigator I. Armas, as well as on short research grants of the main author in frame of the COST action TU0801, grant COST-STSM-TU0801021120 at the University of Algarve, Portugal, and in frame of the Network for Digital Methods in Arts and Humanities, grant 5454 at the Karlsruhe Institute of Technology, Germany, the later about 3-D GIS issues.

Edited by: K. Tokeshi

Reviewed by: G. M. Dawod and one anonymous referee 


\section{References}

Borzi, B., Pinho, R., and Crowley, H.: Simplified pushover-based vulnerability analysis for large scale assessment of RC buildings, Eng. Struct., 30(3), 804-820, 2008.

Bostenaru Dan, M.: Seven years dedicated to the conservation of the Modern Movement Heritage, e-conservation magazine, 18, http://www.e-conservationline.com/content/view/977, 2011.

Bostenaru Dan, M.: Stereo 3D Applications Potential for Heritage Disaster Management, in: 3D Issues in Urban and Environmental Systems, edited by: Billen, R., Caglioni, M., Marina, O., Rabino, G., San José, R., Societa' Editrice Esculapio, Bologna, 43-50, 2012a.

Bostenaru Dan, M.: Arhitectura interbelică cu structură din beton armat expusă la hazard seismic în context european. Intervenţii în spaţiul românesc şi Italian, doctoral thesis, "Ion Mincu" University of Architecture and Urbanism, Bucharest, Romania, 2012b.

Bostenaru Dan, M.: Interwar architecture with reinforced concrete structure exposed to multihazard in European context, Intervention in the Romanian and Italian context, Reihe: Architektur, Band 11, LIT Verlag, Münster, ISBN 978-3-643-90366-2, 2013a. Bostenaru Dan, M.: Technology in the Architecture of Modernism: The Architectural Heritage, e-conservation magazine, 25, 33-36, http://www.e-conservationline.com/content/view/1097, $2013 \mathrm{~b}$.
Bostenaru Dan, M. and Panagopoulos, T.: Concept for the digital visualisation of the impact of the 1755 Lisbon earthquake, in: Peisaj cultural, arhitectura, tendinte, 120 de ani de invatamant superior de arhitectura/Cultural landscape, architecture trends, 120 years of higher education in architecture, edited by: Mitrache, A. Editura Universitara "Ion Mincu”, Bucuresti, 2012.

Celac, M., Carabela, O., and Marcu Lapadat, M.: Bucuresti, Arhitectură şi Modernitate, Un Ghid Adnotat, Simetria, Bucharest, 2005 (in Romanian).

Florescu, T.: Formă şi trans-formare urbană, Editura Universitara "Ion Mincu", Bucharest, 2006 (in Romanian).

Gociman, C. O.: Managementul reducerii riscului la dezastre: strategii de arhitectura si urbanism, Editura Universitara "Ion Mincu", Bucuresti, 2006 (in Romanian).

Prager, E.: Betonul armat în România, Editura Tehnica: Bucharest, 1979 (in Romanian).

Smărăndescu, P.: Lucrări de architectură 1907-1942, Tip. Universul, Bucharest, 1942 (in Romanian). 